\title{
Research Article: Changes in quality of dried-on-vine (DOV) raisins as influenced by pre-drying treatments and seedless varieties of grape (Vitis vinifera L.)
}

A. VENKATRAM, A.S. PADMAVATHAMMA, K. MANORAMA AND D. VIJAYA

Article Chronicle : Received :

05.07.2017;

Accepted :

22.07.2017

KEY Words:

Antioxidants, Ethyl

oleate, Dried-on-vine, Raisin color, Sugar, ascorbic acid

Author for correspondence :

\section{A. VENKATRAM}

College of Agriculture,

Professor Jayashankar

Telangana State

Agricultural University,

Rajendranagar,

HYDERABAD

(TELANGANA) INDIA

Email:venkatramambotu@ gmail.com

See end of the article for authors' affiliations
SUMMARY : The study was planned and executed in the Grape Research Station, Hyderabad, to study the influence of various concentrations of antioxidants (ascorbic acid, AA $500 \mathrm{ppm}, 750 \mathrm{ppm}$ and 1000 ppm and benzyl adenine, BA $50 \mathrm{ppm}, 100 \mathrm{ppm}$ and $150 \mathrm{ppm}$ ) with alkaline emulsion of ethyl oleate (AEEO, $2.4 \%$ potassium carbonate $+1.5 \%$ ethyl oleate) as a pre-drying treatment on quality of driedon-vine (DOV) raisins prepared from seedless grape varieties viz., Thompson seedless, 2A Clone, Sonaka, Manik Chaman and Merbein seedless. The grape bunches were dried on the vine after severing the fruit bearing canes and leaving the canes that will carry the next year's crop. The fruit bearing canes are then sprayed with drying emulsions and harvested raisins are finally dried in dehydrators. Results showed that the various concentrations of antioxidants with AEEO influence colour homogeneity but not size and surface texture of raisins whereas these are affected by varieties. DOV raisins prepared by using AEEO plus AA $1000 \mathrm{ppm}$ as a pre-drying treatment recorded lowest percentage of brown and mixed colour and correspondingly increased green colour. Among the different pre-drying treatments used for raisin making, AEEO plus AA $1000 \mathrm{ppm}$ was superior than others with respect to acidity, total soluble solids, sugar (total, reducing and non-reducing) and ascorbic acid content of DOV raisins. Regarding varieties, DOV raisins prepared from varieties Thompson seedless and Manik Chaman were superior to others.

How to cite this article : Venkatram, A., Padmavathamma, A.S., Manorama, K. and Vijaya, D. (2017). Changes in quality of dried-on-vine (DOV) raisins as influenced by pre-drying treatments and seedless varieties of grape (Vitis vinifera L.). Agric. Update, 12(TECHSEAR-1) : 9-17; DOI: 10.15740/HAS/AU/12.TECHSEAR(1)2017/ 9-17. 